\title{
PERANAN BMT AR-RAHMAH TERHADAP PENGEMBANGAN EKONOMI UMMAT DI KECAMATAN PANCA RIJANG KABUPATEN SIDENRENG RAPPANG
}

\author{
${ }^{1)}$ Muhammad Abduh Anwar, 2)Muhammad Aslam Ahmad, ${ }^{3)}$ Zulkarnanin Sulaiman \\ Fakultas Ekonomi dan Bisnis Universitas Muhammadiyah Sidenreng Rappang \\ muhabduhanwar@umsrappang.ac.id \\ aslam@ddipolman.ac.id \\ Zulkarnain@umsrappang.ac.id
}

\begin{abstract}
Abstrak
Penelitian ini dua masalah pokok, yakni: pola pelayanan BMT Ar-Rahmah Rappang sebagai mutu peningkatan ekonomi umat dan tingkat perubahan ekonomi menyangkut pembiayaan BMT ArRahmah dengan tujuan menilai titik kepuasan Nasabahnya. Penelitian ini sebetulnya mendeskripsikan pola atau bentuk pelayanan yang di implementasikan oleh BMT Ar-Rahmah Rappang dengan sebagai mutu peningkatan dan perubahan ekonomi umat tujuannya adalah untuk menilai titik kepuasan Nasabahnya. Dalam pengumpulan data, digunakan metode library research dan field research dengan menggunakan tehnik observasi wawancara dan dokomentasi. Data yang terkumpul diolah dengan menggunakan metode indukatif dan deskriptif. Hasil penelitian didapatkan bahwa BMT Ar-Rahmah Rappang sebagai lembaga usaha keuangan ekonomi mikro syariah yang dipercaya masyarakat. Dalam usahanya menjaga dan memelihara eksistensinya dalam persaingfan yang begitu ketat maka BMT senantiasa berusaha menjalankan fungsi pelayananya dengan baik melalui pola pelayanan yang profesional dan beretika islami, dengan berbagai bentuk pelayanan yang mencakup penyediaan sarana dan prasarana, produk-produk keuangan yang inovatif, dan kinerja karyawan sehingga nasabah selalu merasa puas. Dan eksisistensinya sebagai lembaga pemberdayaan ekonomi umat khususnya kalangan menengah kebawah sehingga tumbuh dan berkembang.
\end{abstract}

Kata Kunci : Pola Pelayanan, Tingkat Kepuasan Nasabah

\begin{abstract}
In this research, there are two main problems, namely: the service pattern of BMT Ar-Rahmah Rappang as the quality of the community's economic improvement and the level of economic change concerning Rappang in the financing of BMT Ar-Rahmah to assess the point of satisfaction of its customers. This research describes the pattern or form of service implemented by BMT Ar-Rahmah Rappang with the quality of improvement and economic change in the ummah; its purpose is to assess the point of customer satisfaction. In data collection, used library research methods and field research using interview observation techniques and documentation. The collected data were processed using the descriptive and inductive methods. The results showed that BMT Ar-Rahmah Rappang is a sharia microeconomic financial business institution that is trusted by the public. In an effort to maintain and maintain its existence in such a tight competition, BMT always tries to carry out its service functions properly through professional service patterns and Islamic ethics, with various forms of services including the provision of facilities and infrastructure, innovative financial products, and employee performance. So that customers are always satisfied, and its existence as an institution for economic empowerment of the people, especially the middle to the lower class, so that it grows and develops.
\end{abstract}

Keywords: Service Patterns, Customer Satisfaction

JIA | Volume 9 | Nomor 1 | Edisi April 2021 


\section{A. PENDAHULUAN}

Krisis yang multidimensional hanya dirasakan oleh kalangan masyarakat kecil dan tidak dirasakan oleh kalangan masyarakat elit. Rumah mewah, mobil mewah diperebutkan dan tidak pernah mencukupi permintaan pasar. Sementara pada sisi lainnya pengusaha menengah ke bawah mengalami kerugian karena hasil produksinya tidak mampu bersaing dengan permintaan pasar yang ada. Fenomena ini menarik untuk dicari akar masalahnya dengan meneropong kembali akar masalah yang menyingkapi perekonomian saat ini.

Salah satu upaya yang harus dilakukan adalah mengupayakan peningkatan produktivitas. Untuk meningkatkan produktivitas, salah satu faktor penunjang yang penting adalah ketersediaan modal yang cukup. Kendala permodalan bagi umumnya pengusaha kecil tidak mampu diatasioleh perbankan modern. Pada umumnya penerapan sepertibunganya tinggi tidak ada administrasi yang tertib dan baik, serta tidak ada unsur pematangan ekonomi yang sifatnya mendidik masyarakat penerima kredit (modal) tersebut.

Kondisi ini semakin memperlebar jarak antara usaha kecil dan sektor informal dengan industri perbankan formal. Untuk itu, diperlukan adanya sistem kredit yang mampu menjangkau lapisan masyarakat terbawah dan pada saat yang bersamaan mendorong kesiapannya untuk meningkatkan performance usaha, sehingga lambat laun menjadi layak bank. Baitul Mal wa Tamwil merupakan balai usaha mandiri terpadu yang isinya berintikan bayt al-mal wa al-tamwil dengan kegiatan mengembangkan usahausaha produktif dan investasi dalam meningkatkan kualitas kegiatan ekonomi pengusaha kecil bawah dan kecil dengan antara lain mendorong kegiatan menabung dan menunjang pembiayaan ekonominya.

Peran umum BMT yang dilakukan adalah melakukan pembinaan dan pendanaan yang berdasarkan sistem syariah. Peran ini menegaskan arti penting prinsip-prinsip syariah dalam kehidupan ekonomi masyarakat. Sebagai lembaga keuangan syariah yang bersentuhan langsung dengan kehidupan masyarakat kecil yang serba cukup, ilmu pengetahuan ataupun materi, maka BMT mempunyai tugas penting dalam mengembang misi kelslaman dalam segala aspek kehidupan masyarakat. Dengan kehadiran Baitul Mal Wa Tamwil (BMT) ini diharapkan banyak mampu menyerap masyarakat yang kegiatan ekonominya atau usaha-usaha yang hanya memerlukan modal yang tidak banyak, sehingga dapat mengatasi kesenjangan sosial masyarakat (kemiskinan dan pengangguran). Disamping itu, melalui BMT merupakan salah satu strategis dalam mengatasi kekurangan modal yang selalu menjadi kesulitan usaha-usaha kecil dalam mengembangkan usahanya.

Sebagaimana halnya pada masyarakat Kec. Panca Rijang Kab. Sidrap yang kebanyakan bergerak di bidang perdagangan atau usaha-usaha kecil dapat merasakan Kehadiran BMT sebagai salah satu lembaga keuangan syariah yang lahir dan nuansa baru terutama dalam hal meningkatkan kiprah ummat Islam dan pembangunan nasional. tercermin dalam kegiatan ekonomi di tengahtengah masyarakat yang memegang peranan penting serta turut berpengaruh langsung terhadap kehidupan perekonomian masyarakat.

Sesungguhnya terdapat jenis lembaga keuangan lain diluar perbankan. Lembaga ini sama-sama memiliki keutamaan yang jelas sistem operasionalnya menggunakan syariah islam, hanya produk dan manajemennya sedikit berbeda dengan industri perbankan, lembaga tersebut meliputi Asuransi Syariah, Reksadana Syariah, serta Baitul Maal Wa Tamwil (BMT). Diantara lembaga tersebut yang terkait langsung dengan upaya pemberantasan kemiskinan adalah Baitul Maal Wa Tamwil (BMT). BMT merupakan kependekan dari Baitul Mall wa Tamwil atau dapat ditulis baitul maal wa baitul tanwil. Secara harfiah/ lughawi baitul mall berarti rumah dana dan baitul maal dikembangkan berdasarkan sejarah pekembangannya. Yakni dari masa nabi sampai masa nabi sampai abad pertengahan perkembangan islam dimana baitul maal berfungsi mengumpulkan Sekaligus mentasyarufkan dana sosial, sedangkan baitul maal merupakan lembaga yang bermotif laba.

Sebagai lembaga bisnis, BMT lebih memgembangkan usahanya pada sektor keuangan, yakni simpan pinjam. Usaha ini seperti perbankan yakni menghimpun dana anggota calon anggota (nasabah) serta menyalurkannya kepada sektor ekonomi yang halal dan mengungtungkan. Namun demikian, terbuka luas bagi BMT untuk mengembangkan lahan bisnisnya kepada 
sektor rill maupun sektor keuangan yang dilarang dilakuka oleh lembaga keuangan bank. Karena BMT bukan bank, maka ia tidak tunduk kepada aturan perbankan.

Pada dataran hukum di indonesia, badan hukum yang paling mungkin untuk BMT adalah koperasi, baik serba usaha (KSU) maupun simpan-pinjam (KSP). Nmuan demikian sangat mungkin dibentuk perundangan tersendiri, mengingat sistem, operasional BMT tidak sama persis dengan perkoprasian, semisal LKM (Lembaga Keuangan Mikro) Syariah, dll. BMT merupakan pula sebuah lembaga yang tidak saja berorentasi bisnis tetapi juga sosial. Juga lembaga yang tidak melakukan pemusatan kekayaan pada sebagian kecilorang pemilik modal (pendiri) dengan pengisapan mayoritas orang, tetapi lembaga kekayaannya terdistribusi secara meret dan adil. Lembaga lagir dengan kesadaran umat dan ditaqdirkan untuk menolong kelompok mayoritas pengusaha kecil/mikro. Lembaga yang tidak terjebak pada permainan bisnis untuk keuntungan pribadi, tetapi membangun kebersamaan untuk mencapai kemakmuran bersama. Lembaga yang tidak terjebak pada pikiran pragmatis tetapi memiliki konsep idealis yang istiqamah

Pada dasarnya bahwa BMT adalah lembaga mikro yang dioperasikan dengan prinsip bagi hasil menumbuhkembangkan bisnis usaha mikro dalam dalam rangka mengangkat drajat dan martabat serta membela kepentingan kaum fakir miskin, ditumbuhkan atas prakarsa dan modal awal dari tokoh-tokoh masyarakat setempat dengan berlandaskan pada sistem ekonomi yang salam (kesalamatan), berintikan keadilan, kedamaian, dan kesejahteraan yang tidak terlepas dari pegangan Al-Qur'an dan AlHadits. Pada masa Rasulullah SAW ini, Baitul Maal mempunyai pengertian sebagai pihak (al-jihat) yang menangani setiap harta benda kaum muslimin, baik berupa pendapat maupun pengeluaran. Saat itu Baitul Maal belum mempunyai tempat khusus untuk menyimpan harta karena saat itu harta yang diperoleh belum begitu banyak, kalaupun ada, harta yang diperoleh hampir selalu habis dibagi-bagikan kepada kaum muslimin serta dibelanjakan untuk pemelihraan urusan mereka. Rasulullah SAW senantiasa membagikan ghanimah dan seperlima bagian darinya (al-akhmas) setelah usainya peperangan tanpa menunda-nundanya lagi.
Dengan kata lain, beliau segera menginfakkannya sesuia peruntukannya masing-masing. Abu Bakar dikenal sebagai khalifah wara' (hati-hati) dalam masalah harta. Bahkan pada hari kedua setalah beliau di bai'at sebagai khalifah, beliau tetap berdagang dan tidak mau mengambil harta umat dari Baitul Maal untuk keperluan diri dan keluarganya.

Pandangan bahwa BMT berdasarkan Pancasila dan UUD 45 serta berlandaskan Prinsip Syariah Islam, keterpaduan (Kaffah), kekeluargaan/koperasi, kebersamaan, kemandirian, dan profesionalisme. Dengan demikian keberadaan BMT menjadi organisasi syah dan legal. Sebagai lembaga keuangan syariah, BMT harus berpegang teguh pada prinsip-prinsip syariah. Keimanan menjadi landasan hukum atas untuk mau tumbuh dan berkembang. Keterpaduan mengisyaratkan adanya harapan untuk memcapai sukses di dunia dan di juga akhirat keterpaduan antara sisi maal dan tamwil (sosial dan bisnis). kekeluargaan dan kebersamaan berarti upaya untuk mencapai kesuksesan tersebut diraih secara bersama. Kemandirian berarti BMT tidak dapat hidup hanya bergantung pada uluran tangan pemerintah, harus berkembang dari meningkatnya partisipasi anggota dan masyarakat. Untuk itulah pola pengelolaannya harus profesional. Sebagaimana penjelasan dari surah QS al-Baqarah (2) 283 yang berbunyi:

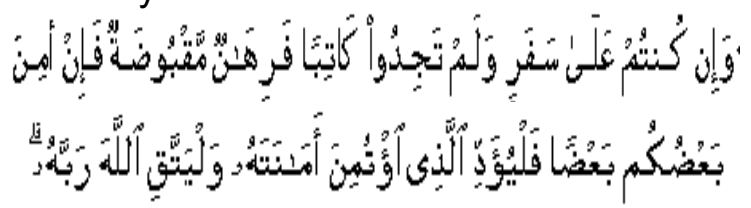

\section{“ Maka Jika sebagian kamu mempercayai sebagian yang lain, maka hendaklah yang dipercayai itu menunaikan amanahnya (utangnya) dan hendaklah ia bertakwa kepada Tuhannya...."}

Tafsir Ibn Katsir menjelaskan bahwa maksudnya sedang melakukan perjalalan, lalu kamu berutang sampai waktu tertentu sedang kamu tidak memperoleh seorang penulis (yang dapat menulis transaksi). Ibn Abbas berkata "atau kamu memperoleh penulis namun tidak ada kertasnya untuk penanya, maka hendaklah ada barang jaminan yang di pegang oleh yang menguntungkan' ayat ini dijadikan dalil oleh sekelompok ulama salaf 
bahwa barang jaminan itu hanya di syariatkan dalam transaksi di perjalanan saja.

Ini jeles-jelas riba tidak peduli namanya berubah dari riba menjadi agunan atau penjualan secara imbal. Sebagaimana hal itu di fatwakan kehalalannya oleh para ulama Mazhaf Hanafi yang mutkhir dan mereka mengistilahanya dengan nama tadi. Itu tidak lain hanyalah nama-nama kamu dan bapakbapak kamu mengadakannya. Allah tidak menurungkan suatu keterangan pun untuk menyembelihnya. menurut gadai yang disyariatkan ialah gadai anda mengadaikan rumah, tanah, atau barang lainnya tanpa ada pemungutan mamfaat oleh penerima dari barang gadai jika penerimaan gadai memungutnya, maka orang yang mengadaikan pun harus mendapatkan yang sama yang besarnya tergantung pada besar kecilnya, mamfaat itu hal itu, karena praktik gadai yang disyariatkan itu tiada lainbahwa barang yang menjadi Agunan itu sebagai jaminan utang jadi jika pemimpin tidak melunasi utangnya pada saat jatuh tempo.

Tujuan tersebut terkait dengan adanya dasar hukum yang mengatur tentang UU Perbankan No. 10/1998, UU Koperasi No. 25/1992 bahwa terdapat beberapa kenyataan yang memberikan landasan kuat pada BMT sebagai gerakan koperasi antara lain: BMT didirikan dengan semangat koperasi, yaitu semangat kekeluargaan bagi anggota yang membutuhkan. Sejarah BMT ada di indonesia di mulai tahun 1984 dikembangkan mahasiswa ITB di Masjid Salman yang mencoba menggulirkan lembaga pembiayaan berdasarkan syariah bagi usaha kecil, kemudian BMT lebih diberdayakan oleh ICMI sebagai gerakan yang secara operasional ditindaklanjuti oleh Pusat Inkubasi Bisnis Usaha Kecil (PINBUK) sebagaimana di uraikan di atas istilah BMT merupakan pengabungkan dari Baitul Maal dan Baitul Tamwil.

Pandangan dan pemahaman yang begitu realistis tak bisa dibantah, bahwa ulama menduduki posisi penting dalam masyarakat islam, ulama tidak hanya sebagai pigur ilmuan yang menguasai dan memahami ajaran-ajaran agama, tetapi juga sebagai penggerak, motivator, dan dinamisator masyarakat kerah pengembangan dan pembanguna umat. Prilaku ulama selalu menjadi teladan dan panutan. Ucapan ulama selalu menjadi pegangan dan pedoman. Ulama adalah pelita umat dan memiliki karisma dalam masyarakat. Penerimaan atau penolakan terhadap suatau gagasan konsep atau program banyak yang dipengaruhi oleh ulama. Peran ulama bukan hanya pada aspek ibadah, memberikan fatwa atau berdoa saja tetapi mencakup berbagi dibidang politik, ekonomi, sosial, budaya, pendidik, keamanan, dan sebagainnya. Sesuai dengan komprehensifan ajaran islam itu sendiri membatasi peran ulama pada persoalan agama, fatwa, dan aklak saja, merupakan kekeliruan besar, karena hal itu dipandang sebagai sebuah historis, sebab sejarah peran ulama sangat luas, seluas dengan ajaran islam yang komprehensif itu pula.

Ulama menjelaskan tentang keunggulan-keunggulan sistem ekonomi islam, termasuk keunggulan sistem bank syariah dari bank konvensional yang menerapkan bunga. Jadi ulama sebenarnya mempunyai peran penting dalam pengembangan produk perbankan syariah. Karena para ulama umumnya menguasai dan bisa mengajarkan fiqih muamalah seperti konsep mudharabah, musyarakah, murabahah, bai' salam, bai' istisna, bai' bittsaman ajil, wakalah, kafalah, hiwalah, ijarah, qardhul hasan,dsb.

Pada level internasional maupun nasional di Jakarta misalnya, peran ulama dalam pengembangan dan sosialisai perbankan dan sosialisasi perbankan syariah cukup besar, tidak seperti yang terjadi di sumatra utara, peran ulama dibilang masih kecil, kalaupun ada dewan pengawas syariah yang berasal dari ulama, perenananya hampir tidak ada, fatwa-fatwa tentang produk-produk semuanya merujuk kepada fatwa Dewan Pengawas Syariah Bank Muamalah di Jakarta. Di Jakarta misalnya para ulama yang berkompoten terhadap hukum-hukum syariah memiliki fungsi dan peran yang amat besar dalam perbankan syariah, yaitu sebagai Dewan Pengawas Syariah dan Dewan Syariah Nasional.

Peran utama para ulama dalam Dewan Pengawas Syariah harus membuat pernyataan secara berkala (biasanya setiap tahun) bahwa bank yang diawasi telah berjalan sesuia degan ketemtuan syariah. Pernyataan dimuat dalam laporan tahunan (annual report) bank syariah tersebut. Tugas lain dari Dewan Pengawas Syariah tersebut.Tugas lain dari Dewan Pengwas ialah meneliti dan membuat rekomondasi produk baru dari bank yang diawasinya. Peran real 
para ulama terlihat pada usaha mendirikan berdirinya Bank Muamalah Indonesia, Asuransi Takaful Syariah, mendirikan Pusat Inkubasi Bisnis Usaha Kecil (PINBUK) yang aktif menumbuhkan Baitul Maal wa Tamwil (BMT).

\section{B. METODE PENELITIAN}

Hasil yang maksimal dari penelitian maka sebagaimana lazimnya, penulis mengemukakan metode yang dipergunakan dalam mengelola materi yang dibahas. Pendekatan Syariat Islam, yaitu pendekatan yang menekankan kepada rujukan Islam yakni, Al-Qur'an dan Al-Hadits nabi atau sunnah Rasulullah sebagai sumber dari syariat Islam, Pendekatan Perbankan, yaitu pendekatan yang menekankan pada sistem, starategi pengembangan lembaga keuangan Syariah. Jenis data yang dilakukan dalam penelitian ini adalah Data Kuantitatif, yaitu data yang di peroleh dari lokasi penelitian dalam bentuk dokumentasi atau tabel untuk selanjutnya di analisis dan Data Kualitatif, yaitu data diperoleh dalam bentuk informasi baik secara lisan maupun tertulis. Sumber data yang digunakan adalah Data Primer, Yaitu data yang di peroleh dari hasil wawancara terhadap pihak-pihak yang dianggap perlu untuk diambil keterangannya. Mengenai masalah-masalah yang akan di bahas dalam karya ilmiah ini. Data Skunder, yaitu Data yang di peroleh melalui studi kepustakaan pada buku, artikel, karya ilmiah, yang berhubungan dengan pembahasan penelitian ini. Penggunaan tehnik pengumpulan data dalam penelitian ini di sesuaikan dengan kebutuhan dan kemampuan peneliti sendiri tanpa maksud mengurangi prosedur yang berlaku. Metode yang digunakan pada tehnik pengumpulan data adalah Penelitian kepustakaan (library research), yaitu tehnik pengumpulan data dengan jalan menelaah buku-buku literatur, artikel, memiliki replevansi dengan pembahasan skripsi ini, Penelitian lapangan (field research), yaitu tehnik pengumpulan data dengan cara terjun langsung kelokasi atau objek penelitian, dimana penulis langsung melekukan penelitian yang akan di teliti. Adapun tehnik yang digunakan adalah Observasi yaitu penelitian yang dilakukan dengan jalan mengadakan pengamatan secara langsung terhadap permasalahan yang akan di kaji. Interview yaitu penelitian yang akan dilakukan dengan jalan melakukan wawancara secara langsung kepada beberapa orang yang terdiri dari, Pihak Manajemen BMT Ar-Rahmah Rappang dan Pihak Nasabah BMT Ar-Rahmah Rappang, Kuisioner yaitu dengan mendistribusikan kuisioner terhadap sejumlah Responden yang meliputi Nasabah BMT Ar-Rahmah Rappang, Dokumentasi yaitu dengan jalan memeriksa segala arsip yang membantu dalam penyelasaian masalah yang ada. Tehnik Analisis Data adalah Tehnik Indukatif yaitu menganalisis data dengan bertolak dari hal yang bersifat khusus, selanjutnya mengambil kesimpulan. Tehnik Deskriptif Kuantitatif yaitu analisis persentase dengan menggunakan rumus distribusi frekuensi yaitu:

\begin{tabular}{|c|c|}
\hline $\mathbf{N}$ & P : Persentase \\
\hline$P=--x 100 \%$ & F : Frekuensi \\
\hline $\mathbf{P}$ & $\begin{array}{l}\text { N:Jumlah Frekuensi } \\
\text { darkategori }\end{array}$ \\
\hline
\end{tabular}

\section{HASIL DAN PEMBAHASAN}

Bahwa Kecamatan Panca Rijang memiliki jumlah penduduk sebanyak 137.221 Jiwa , 25598 orang yang beragama islam, 10 beragama kristen, dan 6 orang beragama hindu. Kecamatan Panca Rijang memiliki beberapa sarana adalah sebagai berikut: Sarana pendidikan mulai dari Taman Kanakkanak sampai Perguruan Tinggi mulai, hal ini dapat dilihat dari jumlah yaitu Taman Kanakkanak (TK) 17 unit, Sekolah Dasar atau Madrasah Ibtidaiyah (SD/MI) 30 unit, Sekolah Menengah Pertama atau Madrasah Tsanawiyah (SMP/MTSN), Sekolah Menengah Atas atau Madrasah Aliyah (SMA/MA) 5 unit, dan Perguruan Tinggi 2 unit. Sarana peribadatan yaitu Masjid 35 unit yang terdiri dari Masjid Besar 1 unit, Masjid Jami' 8 unit, dan Masjid Lingkungan 26 unit. Sarana perekonomian berjumlah 5 unit di antaranya adalah 1 Pasar, 1 Koperasi Unit Desa (KUD), dan 3 unit Simpan Pinjam. Sarana soaial lainnya adalah Panti Asuhan 1 unit. 
Tabel 1. Mata Pencaharian Masyarakat Rappang

\begin{tabular}{|c|c|c|}
\hline $\mathrm{N}$ & Mata Pencaharian & Jumlah Jiwa \\
\hline 1. & Petani & 52.342 \\
2. & Pedagang & 23.801 \\
3. & Peternak & 39.226 \\
4. & Pegawai & 21.852 \\
\hline & Jumlah & 137.221 \\
\hline
\end{tabular}

Sumber Data: Kantor Balai Pusat Statistik Kab.Sidrap

Pada bulan Ramadhan pelaksanaan shalat tarawih di masjid-masjid mendapat kunjungan yang cukup banyak dari kaum muslimin dan muslimat dalam wilayah masingmasing. Begitu pula, kegiatan pengajian yang di selenggarakan oleh para Remaja, Anakanak melalui TK/TPA khususnya dalam pembelajaran al-Qur'an dengan menggubnakan metode iqra. Demikian juga dengan kelompok-kelompok Majelis Taklim yang tersebar di berbagai tempat turut pula menambah semaraknyasuasana kehidupan yang religius di Kecamatan Panca Rijang Kabupaten Sidrap. Adapun kegiatan umat lain seperti Agama Kristen yaitu acara kebaktian di rumah Pendeta pada setiap hari minggu. Menurut Pak Johanes yang mengatakan bahwa "jika ada acara keagamaan yang ingin di laksanakan oleh Para Jama'ah, khususnya pada acara kebaktian akan di tempatkan di rumahnya masing-masing. Karena belum memiliki tempat ibadah, namun mereka mengakui bahwa mereka bersembahyang secara individual di rumahnya masingmasing"

Jadi hubungan antara sesama umat beragama di Kecamatan Panca Rijang Kabupaten Sidrap terjalin cukup baik di dalam kehidupan sosial kemasyarkatan dan nampak pula dengan adanya kebebasan untuk melaksanakan kegiatan ibadah menurut agamanya masing-masing. Pembiayaan Mudharabah adalah suatu perjanjian usaha antara pemilik modal dengan pengusaha, di mana pihak pemilik modal menyediakan seluruh dana yang diperlukan dan pihak pengusaha melakukan pengeloaan atas usaha.

"Data Perkembangan Tabungan Mudharabah dan Potensi Pembiayaan Mudharabah BMT Ar-Rahmah Rappang Kec. Panca Rijang Kab. Sidrap"

\begin{tabular}{|c|c|c|}
\hline Tahun & Nasabah & Simpanan/Saldo \\
& & \\
\hline 2015 & 1.399 & 405.980 .939 \\
2016 & 1.453 & 509.832 .508 \\
2017 & 1.521 & 633.951 .105 \\
2018 & 1.608 & 806. 697.973 \\
\hline Total & 5.991 & 2. 356. 462.525 \\
& & \\
\hline Sumber & Data: Kantor & BMT Ar-Rahmah \\
& Rappang Kec. Panca Rijang Kab. \\
& Sidrap
\end{tabular}

Dari tabel di ketahui bahwa jumlah Nasabah BMT Ar-Rahmah Rappang dari tahun 2019 sampai 2020 secara umum cendung meningkat memperhatikan komposisinya tampa bahwa nasabah tabungan mudharabah memiliki kenaikan besar.

$\begin{array}{lll} & \text { BMT Ar-Rahmah dalam empat tahun } \\ \text { terakhir } & \text { Alhamdulillah menunjukkan }\end{array}$ perkembangan sangat relatif memuaskan. Hal ini dapat dilihat pada indikator keuangan baik dari segi jumlah Dana Pihak Ketiga (DPK) yang berhasil di himpun seperti yang tergambar pada tabel di atas.

Pada tahu 2019, simpanan Masyarakat untuk dikenal sebagai Dana Pihak Ketiga (DPK) yang berhasil di himpun ialah sebesar Rp. 405. 980. 939 dengan jumlah Nasabah 1. 399 orang. Pada tahun 2006 DPK atau Dana Pihak Ketiga meningkat menjadi sebesar Rp. 509. 832. 508 dengan jumlah Nasabah sebesar 1. 453. Tahun 2020, meningkat sebesar menjadi Rp. 633. 951. 105 dengan jumlah Nasabah sebesar 1. 521 orang. Dan terakhir yaitu pada tahun 2008 yaitu DPK meningkat sebesar Rp. 806. 697. 973 dengan jumlah Nasabah 1. 608 orang. Peningkatan DPK tersebut juga mengindikasikan peningkatan kepercayaan 
Nasabah akan Nisbah bagi hasil yang aplikasikan oleh BMT Ar-Rahmah Rappang Kec. Panca Rijang Kab. Sidrap.

Penigkatan perolehan DPK (Dana Pihak Ketiga) juga diiringi oleh penigkatan penyaluran dalam bentuk pembiayaan, sebagaimana yang terlihat pada Tabel sebagai berikut:

\begin{tabular}{|c|c|c|}
\hline Tahun & Jumlah Pembiayaan & Nasabah \\
& & \\
\hline 2016 & 397.223 .975 & 104 \\
2017 & 441.565 .025 & 106 \\
2018 & 406.064 .000 & 109 \\
2019 & 542.411 .425 & 121 \\
\hline Total & 1.787. 264. 425 & 440 \\
\hline Sumber & Data: Kantor BMT Ar-Rahmah \\
& Rappang Kec. Panca Rijang Kab. \\
& Sidrap
\end{tabular}

Pada tahun 2016, pembiayaan yang disalurkan sebesar Rp. 397. 223. 975dengan jumlah Nasabah 104 yang mana sebagian besar pembiayaan yang terserap di sektor perdagangan. Hal ini mengindukasikan produktifitas pembiayaan BMT Ar-Rahmah Rappang Kec. Panca Rijang Kab. Sidrap. Kemudian pada tahun 2017 pembiayaan yang disalurkan ialah sebesar Rp. 441. 565. 025 dengan jumlah Nasabah yaitu 106. Sementara pada tahun 2018, pembiayaan yang disalurkan meningkat sebesar Rp. 406. 064. 000 dengan jumlah Nasabah yaitu 109. Pada tahun 2019, pembiayaan yang disalurkan meningkat sebesar Rp. 542. 411. 425 dengan jumlah Nasabah 121. Jadi total pembiayaan secara keseluruhan mulai dari tahun 2015 2018 yaitu meningkat sebesar Rp. 1. 787.264. 425 dengan jumlah Nasabah yaitu 440 debitur (peminjam).

Pembiayaan Musyarakah adalah suatu perjanjian usaha antara dua atau beberapa pemilik modalnya pada suatu proyek, di mana masing-masing pihak mempunyai hak untuk ikut serta, mewakili atau menggurkan dalam manajemen proyak. Pembiayaan Murabahah adalah pembiayaan yang di berikan kepada Nasabah dalam rangka pemenuhan kebutuhan produksi (inventori). Pembiayaan Al Bai' Bitsaman Ajil adalah pembelian barang dengan pembayaran cicilan atau pembiayaan yang di berikan kepada Nasabah dalam rangka pemenuhan kebutuhan barang modal (investasi).

Adapun tugas dan wewenag pimpinan dan kepala seksi Baitul Maal wa Tamwil (BMT) Ar-Rahmah Rappang Kecamatan Panca Rijang Kabupaten Sidrap sebagai berikut: Dr. A.R. Mustara, SH (Dewan Pengurus), Mengawasi perkembangan Baitul Maal wa Tamwil (BMT), K.H. Fathuddin Sukkara (Dewan Syariah), Mengawasi pengeluaran warkat-warkat yang di salurkan Baitul Maal wa Tamwil (BMT), H. Syamsuddin Hajji (Ketua Pengurus) Melaksanakan sruktur organisasi yang berlaku di Baitul Maal wa Tamwil (BMT), Muh. Areif Mansyur (Anggota) Melaksanakan sruktur organisasi yang berlaku di Baitul Maal wa Tamwil (BMT), $H$. Haiya Haiyong (Anggota), Melaksanakan sruktur organisasi yang berlaku di Baitul Maal wa Tamwil (BMT), Muntaha Ka. Sadda, S.Sos (Manajer) Melakasanakan kegitan-Kegiatan yang berlaku dalam organisasi Baitul Maal wa Tamwi, seperti pengawasan uang, penyaluran pembiayaan pembukuan dalam Baitul Maal wa Tamwil (BMT), Hj. Mukarramah, SE (Kepala Seksi pembukuan)membuat administrasi pembukuan Baitul Maal wa Tamwil (BMT) Rahmadani, S.Ag (Kepala Seksi Pembiayaan) Melaksanakan Administrasi pembiayaan umum dan gadai yang salurkan oleh Baitul Maal waTamwil (BMT), Nur Alam Pallawai (Kepala seksi Kasir) Melaksanakan kegiatan penerimaan dan pengeluaran dana Baitul Maal wa Tamwil (BMT) dan melayani Nasabah yang ingin menyimpan dananya di Baitul Maal wa Tamwil (BMT).

Sistem pola pelayanan ini menyangkut mekanisme atau diberikan oleh suatu lembaga khususnya lembaga keuangan syariah seperti BMT Ar-Rahmah Rappang. Untuk meningkatkan kualitas Nasabah dalam sistem pelayanan yang terbaik untuk 
Nasabahnya senantiasa berusaha menerapkan pola pelayanan prima dengan pelayanan yang profesional dan beretika. Hal ini dikemukakan oleh Manajer BMT ArRahmah Rappang sebagai hasil wawancara kami sebagai berikut :

"Pelayanan di BMT Ar-Rahmah telah membantu Nasabah dalam peningkatan mutu profesonalisme kerja secara islami dan membantu menumbuhkan tarap ekonomi Nasabah yang terkena dampak krisis ekonomi."

Untuk memberikan servis plus kepada para Nasabah dapat dimulai dari kondisi tempat pelayanan tersebut di berikan sebagai mana yang terlihat saat ini. Kondisi Kantor BMT ArRahmah terdiri bangunan yang sangat parmanen yang berlantai satu yang terdiri dari: Ruang tunggu, Teller 1 loket, Unit pendanaan 1 loket, Unit pembiayaan 1 loket, Unit pembukuan 1 loket, Hal ini di benarkan oleh staf BMT Ar-Rahmah, sebagai hasil wawancara kami sebagai berikut:

" Bahwa BMT Ar-Rahmah hanya memiliki satu lantai saja di dalamnya terdapat empat fasilitas komputer, serta satu ruangan manajer, bagi staf memiliki ruangan yang berada di depan ruangan manajer. Umumnya agar nanti Nasabah merasa nyaman dan melayani mereka dalam kegiatan transaksi di Kantor BMT Ar-Rahmah Rappang "

Dalam dalam menjalankan kegiatan operasioanalnya, BMT Ar-Rahmah Rappang melaksanakan perang dasar sebagai lembaga intermedisasi yang menawarkan ragan produk dengan bagi hasil yang menguntungkan yang memenuhi kebutuhan akan produk. BMT ArRahmah mempunyai produk-produk yang terdiri atas Produk Pendanaan (Tabungan Mudharabah) dan Produk Pembiayaan (Musyarakah, Murabahah, dan Al Bai Bitsaman Ajil) dengan nisbah bagi hasil yang di tentukan atau pun menurut kesepakatan antara pihak pengelola BMT dan Nasabah di mana nantinya pihak Nasabah sendiri yang memiliki akan meggunakan produk apa sesuai dengan kebutuhannya. Sebagaimana pernyataan Kepala Seksi Pembiayaan hasil wawancara sebagai berikut:

“ Adanya produk-produk yang ditawarkan oleh pihak BMT Ar-Rahmah Rappang, maka Nasabah akan memilih produk tersebut sesuai dengan pilihannya masing-masing, tugas kami nantiya akan melayani Nasabah sesuai dengan pilihannya masing-masing"

Melayani bahwa salah satu faktor penilaian terhadap kualitas pelayanan suatu lembaga keuangan. Apakah pelayanan yang di berikan sudah baik atau sebaliknya adalah dengan memperoleh bagaimana kinerja akan pemberi layanan tersebut dalam hal karyawan BMT Ar-Rahmah Rappang.

Etika dalam memberikan pelayanan merupakan suatu hal yang penting, karena lansung dirasakan oleh nasabah. Semakin baik etika karyawan dalam melayani nasabah maka semakin nyaman pula perasaan Nasabah ketika menerima pelayanan tersebut. Untuk itu karyawan BMT Ar-Rahmah Rappang senantiasa menjadikan etika sebagai dasar memberi pelayanan, hal ini dapat di lihat dari cultur salam, senyum dan sapa yang senantiasa di terapkan kesehariannya dalam melayani Nasabah.

Hal ini dapat di benarkan oleh salah satu Nasabah, sebagaimana hasi wawancara sebagai berikut:

" Ketika saya ingin menabung para staf saling memberikan senyuman, salam dan sapa kepada saya. Kemudian saya merasa sangat nyaman pada saat para staf tersebut melayani seperti itu. Saya rasa bahwa pelaksanaan yang berada di BMT Ar-Rahmah betul-betul sangat baik dan memuaskan Nasabah "

Dalam arti bahwa prosedur pelayanan terhadap kebutuhan Nasabah yang di berikan secara mudah, lancar, cepat dan tidak berbelit-belit karena Nasabah langsung dilayani oleh staf atau karyawan yang menangani transaksi yang nasabah butuhkan tersebut sehingga dapat mengefesienkan waktu Nasabah. Sebagaimana pernyataan salah seorang Kepala Seksi Pembiayaan hasil wawancara sebagai berikut: 
“Sebelum Nasabah melakukan transaksi, kami harus menanyakan terlebih dahulu kemudian nantinya Nasabah memilih dengan sesuka hatinya"

Dari hasil observasi sudah jelas bahwa, pola pelayanan dalam meningkat kan tarap ekonomi nasabah BMT Ar-Rahmah Rappang sudah menjadi gambaran terhadap masyarakat. Pola pelayanan prima sangatlah di butuhkan dalam kehidupan sehari-hari sehingga telah menjadi media solusi dan pengembangan ekonomi umat untuk mengimplementasikan tahapan-tahapan

\begin{tabular}{|c|c|c|}
\hline Tingakat Pendidikan & Frekuensi & Persentase \\
\hline SMP atau MTS & 6 & $12 \%$ \\
SMA atau MA & 12 & $24 \%$ \\
DIPLOMA & 6 & $12 \%$ \\
S1 & 25 & $50 \%$ \\
S2 & 1 & $2 \%$ \\
\hline TOTAL & 50 & $100 \%$ \\
\hline
\end{tabular}

perekonamian dengan jalan secara syariah

Untuk mengetahui tingkat kepuasan Nasabah terhadap peningkatan kualitas pelayanan atau perkembangan ekonomi umat pada BMT Ar-Rahmah Rappang. Maka peneliti mendistribusikan kuisioner pada Nasabah BMT Ar-Rahmah Rappang yang terdiri dari atas, Penelitian di lakukan terhadap 50 Nasabah BMT Ar-Rahmah Rappang dengan sebaran distribusi kuisioner sebagai berikut:

Tabel 5. Tabulasi Nasabah Berdasarkan Jenis Kelamin

\begin{tabular}{|c|c|c|}
\hline Jenis Kelamin & Frekuensi & Persentase \\
\hline Laki-laki & 23 & $46 \%$ \\
Perempuan & 27 & $54 \%$ \\
\hline Total & 50 & $100 \%$ \\
\hline
\end{tabular}

Sumber Data: Diolah dari data primer

Tabel di atas memperlihatkan bahwa $46 \%$ sebanyak 23 responden merupakan laki-laki, dan $54 \%$ atau sebanyak 27 responden adalah perempuan.
Tabel 6. Tabulasi Nasabah Berdasarkan Usia

\begin{tabular}{|c|c|c|}
\hline Kelompok Usia & Frekuensi & Persentase \\
\hline $11-20$ & 6 & $12 \%$ \\
$21-30$ & 15 & $30 \%$ \\
$31-40$ & 10 & $20 \%$ \\
$41-50$ & 11 & $22 \%$ \\
Lebih dari 50 & 8 & $16 \%$ \\
\hline Total & 50 & $100 \%$ \\
\hline
\end{tabular}

Sumber Data: Diolah dari data primer

Tabel data di atas menunjukkan bahwa dari 50 responden. 6 orang atau sebesar $12 \%$ responden tergolong kelompok usia yaitu 11 sampi 20 tahun, 15 orang atau sebesar $30 \%$ responden tergolong usia 21 sampai 30 tahun, 10 orang atau sebesar $20 \%$ responden tergolong usia 31 sampai 40 tahun, 11 orang atau sebesar $22 \%$ responden tergolong kelompok usia 41 sampai 50 tahun, dan sebanyak orang atau $16 \%$ berusia di atas 50 tahun.

Tabel 8. Tabulasi Nasabah Berdasarkan Pekerjaan

\begin{tabular}{|c|c|c|}
\hline Pekerjaan Nasabah & Frekuensi & Persentase \\
\hline Pelajar/Mahasiswa & 10 & $20 \%$ \\
Honorer & 8 & $16 \%$ \\
PNS & 18 & $36 \%$ \\
Wiraswasta & 14 & $28 \%$ \\
\hline Total & 50 & $100 \%$ \\
\hline
\end{tabular}

Sumber Data: Diolah dari data primer

Tabel di atas menunjukkan bahwa dari 50 Nasabah, 10 orang atau sebesar $20 \%$ merupakan pelajar atau mahasiswa, 8 orang atau sebesar $16 \%$ merupakan honorer, 18 orang atau sebesar $36 \%$ merupakan PNS, dan 14 orang atau sebesar $28 \%$ merupakan wiraswasta. Adapun objek penilaian yang digunakan untuk mengetahui tingakt kepuasan Nasabah terhadap peningkatan pelayanan atau perkembangan ekonomi umat pada BMT Ar-Rahmah Rappang Kecamatan Panca Rijang Kabupaten Sidrap yang meliputi fasilitas sarana dan prasarana, ragam produk serta nisbah bagi hasilnya. Dan kualitas pelayanan karyawan yang di maksud adalah para pegawai atau karyawan meliputi Kepala Seksi Pembukuan, Kepala Seksi Pembiayaan, Kepala Seksi Kasir, dan Manajer Umum 
dengan untuk mengetahui hasil dari penilaian tersebut, maka dapat dilihat pada tabel-tabel sebagai berikut:

Tabel 9. Penilaian Fasilitas Sarana dan Prasarana BMT Ar-Rahmah Rappang

\begin{tabular}{|c|c|c|}
\hline Indikator & Frekuensi & Persentase \\
\hline Sangat memuaskan & 17 & $34 \%$ \\
Memuaskan & 30 & $60 \%$ \\
Cukup memuaskan & 3 & $6 \%$ \\
Tidak memuaskan & 0 & $0 \%$ \\
\hline Total & 50 & $100 \%$ \\
\hline
\end{tabular}

Sumber Data: Diolah dari data primer

Tabel di atas menunjukkan bahwa dari 50 responden yang di jadikan sampel penelitian dari Nasabah BMT Ar-Rahmah Rappang, maka hasil tabulasi menunjukan bahwa 17 responden atau sebesar 34\% yang menyatakan fasilitas sarana dan prasana yang ada pada BMT Ar-Rahmah Rappang yaitu sangat memuaskan, 30 responden atau sebesar $60 \%$ menyatakan memuaskan, yang menyatakan cukup memuaskan hanya sebesar 3 responden atau $6 \%$, dan yang menyatakan tidak memuaskan $0 \%$.

Dari persentase tersebut menjelaskan bahwa fasilitas sarana dan prasarana yang ada pada BMT Ar-Rahmah Rappang, menyatakan telah memuaskan Nasabah.

Hal ini menggambarkan bahwa fasilitas sarana dan prasarana sangatlah penting keberadaanya untuk menunjukkan operasional dari BMT Ar-Rahmah Rappang, yang terdiri dari bangunan berlantai satu dengan masing-masing, beberapa di antaranya yaitu sistem komputer yang saling terkoneksi, memiliki ruangan yang sederhana serta tersedianya kelengkapan brosur menegenai produk yang ada sehingga dapat memuaskan nasabahnya, hal ini dibenarkan oleh salah satu Nasabah dalam hasil wawancara sebagai berikut:

“ Saya rasa fasilitas saranadan prasarana yang ada di kantor BMT Ar-Rahmah Rappang sudah cuckup memadai, hal itu bisa saya lihat dari kondisi kantor dengan ruangan unit kerja yang tertata rapi dan tempat unit kerjanya, gampang di dapat tentang fasilitasnya saya merasa puas"

Selain pelayanan yang menyangkut fasilitas sarana dan prasarana, kemudian hal yang terpenting, dari sisi karyawan atau pegawainya yaitu melihat kondisi Nasabahnya yang di artikan dengan Umat. Apakah layak mendepositkan dananya di BMT Ar-Rahmah Rappang, bahwa BMT Ar-Rahmah mempunyai tebungan alternatif yang di beri nama Tabungan Ekonomi Umat, mulai dari tahun 2015 sampai saat sekarang ini, tabungan tersebut dijadikan sebuah penilaian tersendiri bagi masyarakatnya, hal ini ini benarkan oleh Kepala Seksi Pembiayaan BMT Ar-Rahmah Rappang dalam hasil wawancara sebagai beriku

“ Kami menyediakan tabungan ini adalah hasil kesepakatan pihak pengelola dan nasabah BMT Ar-Rahmah Rappang yang tujuannya adalah mempersejahterakan fakir miskin yang betul-betul minim dengan finansial. Maka terbentuknya tabungan ekonomi umat masyarakat tidak lagi terbebani dengan minimnya kebutuhan mereka"

Dari ragam dan keuntungan nisbah bagi hail dari produk tersebut, karena pihak BMT ArRahmah Senantiasa menawarkan produk keuangan dengannisbah yang sangat jelas. Sebagaimana pernyataan Manajer Umum BMT Ar-Rahmah Rappang dari hasil wawancara sebagi berikut:

Dengan adanya penawaran tentang produkproduk yang meliputi produk pendanaan dan pembiayaan dengan keuntungan nisbah bagi hasil yang jelas terhadap masing-masing produk kebutuhan akan produk bisa terpenuhi

Tabel 10. Penilaian Ragam Produk BMT ArRahmah Rappang

\begin{tabular}{|c|c|c|}
\hline Indikator & Frekwensi & Persentase \\
\hline Sangat memuaskan & 5 & $10 \%$ \\
Memuaskan & 35 & $70 \%$ \\
Cukup memuaskan & 7 & $14 \%$ \\
Tidak memuaskan & 3 & $6 \%$ \\
\hline
\end{tabular}




\begin{tabular}{|c|c|c|}
\hline Total & 50 & $100 \%$ \\
\hline
\end{tabular}

Sumber Data: Diolah dari data primer

Tabel di atas menunjukkan bahwa dari 50 responden yang di jadikan sampel peneliti dari Nasabah BMT Ar-Rahmah Rappang, maka hasil tabulasi menunjukkan bahwa 5 responden atau $10 \%$ bahwa ragam produk BMT Ar-Rahmah Rappang yang di tawarkan sangat memuaskan, 35 responden atau $70 \%$ bahwa ragam produk yang ditawarkan menyatakan memuaskan, 7 responden atau $14 \%$ bahwa menyatakan cukup memuaskan, dan 3 responden atau $6 \%$ yaitu menyatakan tidak memuaskan. Dari persentase tersebut menjelaskan bahwa dalam hal pemenuhan akan ragam produk yang ada pada BMT ArArahmah Rappangtelah memuaskan Nasabah .

Di samping itu, penilaian yang berhubungan dengan keuntungan nisbah bagi hasil terhadap produk BMT Ar-Rahmah Rappang. Hal ini tercantum pada tabel sebagai berikut:

Tabel 11. Tabulasi Penilaian Keuntungan Nisbah Bagi Hasil Terhadap Produk BMT ArRahmah Rappang.

Sumber Data: Diolah dari data primer

Tabel di atas di atas menunjukkan bahwa dari 50 responden yang di jadikan sampel peneliti dari Nasabah BMT Ar-Rahmah Rappang, maka hasil tabulasi menujukkan bahwa 5 respoden atau $10 \%$ bahwa ragam produk BMT Ar-Rahmah Rappang yang di tawarkan sangat memuaskan, 35 responden atau $70 \%$ yang menyatakan memuaskan, 7 responden atau $14 \%$ bahwa menyatakan cukup memuaskan, dan 3 responden atau $6 \%$ yaitu menyatakan tideak memuskan. Dari persentase tersebut menjelaskan bahwa dalam hal pemenuhan akan ragam produk

\begin{tabular}{|c|c|c|}
\hline Indikator & Frekwensi & Persenrase \\
\hline Sangat memuaskan & 5 & $10 \%$ \\
Memuaskan & 35 & $70 \%$ \\
Cukup memuaskan & 7 & $14 \%$ \\
Tidak memeuaskan & 3 & $6 \%$ \\
\hline Total & 50 & $100 \%$ \\
\hline
\end{tabular}

BMT Ar-Rahmah Rappang hal ini tercantum pada tabel sebgai berikut:
Tabel 12. Tabulasi Penilaian Keuntungan Nisbah Bagi HasilTerhadap Produk BMT ArRahmah Rappang

\begin{tabular}{|c|c|c|}
\hline Indikator & Frekwensi & Persentase \\
\hline Sangat Memuaskan & 10 & $20 \%$ \\
Memuaskan & 37 & $74 \%$ \\
Cukup memuaskan & 3 & $6 \%$ \\
Tidak memuaskan & 0 & $0 \%$ \\
\hline Total & 50 & $100 \%$ \\
\hline
\end{tabular}

Sumber Data: Diolah dari data primer

Tabel di atas menunjukkan bahwa dari 50 responden yang di jadikan sampel penelitian dari Nasabah BMT Ar-Rahmah Rappang, bahwa 10 responden atau $20 \%$ yang menyatakan keuntungan nisbah bagi hasilnya sangat memuaskan, 37 responden atau $74 \%$ mentyatakan memeuaskan, sedangkan yang menyatakan cukup memeuaskan hanya 3 responden atau $6 \%$, dan tidak memuaskan 0\%. Dari persentase tersebut menjelaskan bahwa pelayanan dalam hal keuntungan nisbah bagi hasil terhadap produk-produk BMTAr-Rahmah Rappang telah memuaskan Nasabah atau umat. Sebagaimana yang di benarkan dari salah satu Nasabah BMT Ar-Rahmah Rappang dari hasil wawancara sebagai berikut:

" saya selaku Nasabah tentang keuntunga nisbah bagi hasilnya dari berbagai macam produk yang ada pada BMT Ar-Rahmah, telah betul-betul menguntungkan bagi saya salah satu produk BMT Ar-Rahmah Yang Saya pilih mulai tahun 2000 yaitu pembiayaan musyarakah dimana saya memilih produk ini keuntungan nisbah bagi hasilnya betul-betul murni "

Di samping penilaian tentang keuntungan nisbah bagi hasilya, hal yang terpenting adalah bagaimana kinerja karyawan dalam bertransaksi dengan nasabah, untuk itu ada beberapa penilaian yang di lakukan untuk mengetahui tingkat kepuasan Nasabah terhadap pelayanan sebagai mana yang terlihat pada tabel di bawah ini. 
Tabel 13. Penilaian Kecepatan dan

Keakuratan Karyawan

dalam Memberi Pelayanan

\begin{tabular}{|c|c|c|}
\hline Indikator & Frekwensi & Persentase \\
\hline Sangat & 16 & $32 \%$ \\
memeuaskan & 29 & $58 \%$ \\
Memuaskan & 5 & $10 \%$ \\
Cukup & 0 & $0 \%$ \\
memuaskan & & \\
Tidak memuaskan & & \\
\hline Total & 50 & $100 \%$ \\
\hline
\end{tabular}

Sumber Data: Diolah dari data primer

Tabel di atas menunjukkan bahwa dari 50 responden yang dijadikan sampel peneliti dari Nasabah BMT Ar-Rahmah Rappang, maka hasil tabulasi menunjukkan bahwa dari 16 responden atau $32 \%$ yang menyatakan bahwa kecepatan karyawan dalam memberi pelayanan fasillitas sarana dan prasarana yang ada pada BMT Ar-Rahmah Rappang yaitu sangat memuaskan, 29 responden atau $58 \%$ menyatakan memuaskan, 5 responden atau $10 \%$ yang menyatakan cukup memuaskan, dan menyatakan tidak memuaskan adalah $0 \%$.

Dari persentase tersebut sudah jelas bahwa kecepatan dan keakuratan karyawan dalam memberi pelayanan kepada nasabah BMT Ar-Rahmah telah memuaskan. Hasil kuisioner ini di pertegaskan oleh pernyataan salah datu Nasabah sebagaimana hasil wawancara sebagai berikut:

"selama pihak pegawai/karyawan BMT ArRahmah melayani saya, masalah kecepatan dan keakuratan karyawan itu cukup baik serta waktu pun menjadi terefesienkan"

Tabel di atas menunjukkan bahwa 50 responden yang dijadikan sampel peneliti Nasabah BMT Ar-Rahmah Rappang, maka hasil tabulasi menunjukkan bahwa 7 responden atau $14 \%$ yang menyatakan bahwa keramahan karyawan dalam memberi pelayanan menyangkut fasilitas sarana dan prasarana yang ada pada BMT Ar-Rahmah Rappang adalah sangat memuaskan 43
Tabel 14. Keramahan Karyawan dalam memberi pelayanan

\begin{tabular}{|c|c|c|}
\hline Indikator & Frekwensi & Persentase \\
\hline Sangat & 7 & $14 \%$ \\
memeuaskan & 43 & $86 \%$ \\
Memuaskan & 0 & $0 \%$ \\
Cukup & 0 & $0 \%$ \\
memuaskan & & \\
Tidak memusakan & & \\
\hline Total & 50 & $100 \%$ \\
\hline
\end{tabular}

Sumber Data: Diolah dari data primer.

responden atau $86 \%$ menyatakan memuaskan, sedangkan yang menyatakan cukup memuaskan dan tidak memuaskan $0 \%$. Dari persentase tersebut menjelaskan bahwa keramahan karyawan dalam memberi pelayanan merupakan bentuk etika terwujud dari budidaya kerja yang baik selama ini diterpkan oleh BMT Ar-Rahmah Rappang, yabg berada di Kecamatan Panca Rijang Kabupaten Sidrap.

\section{KESIMPULAN}

BMT Ar-Rahmah Rappang merupakan badan atau lembaga yang meningkatkan kinerja perekonomian dan sekaligus dapat mengentaskan kemiskinan sehingga tercapai kesejahteraan umat, oleh karena itu untuk mewujudkan peran BMT dalam perekonomian tersebut di perlukan peran pemerintah yang intensif tyerhadap eksistensi BMT Ar-Rahmah itu sendiri. Disamping itu ada dukungan dari masyarakat besarnya umat islam untuk mengembangkan dari segi permodalan maupun peningkatan berkualitas sumber daya manusia (SDM).

Sebagai salah satu lembaga keuangan mikro syariah, BMT Ar-Rahmah Rappang dapat semakin memberikan pola pelayanan yang baik kepada Nasabahnya. Dengan melalui pola pelayanan kinerja sebagai profesional dan beretika islam, sehingga perannya sebagai lembaga pengembangan ekonomi umat akan senantiasa tumbuh dan berkembang.

Dengan adanya pola pelayanan yang preofesional dan beretika islam yang di terpkan oleh BMT Ar-Rahmah Rappang telah 
memberikan kepuasan terhadap Nasabah. Hal ini terlihat pada hasil kuisioner dan wawancara kepada Nasabah yang terdiri dari beberapa objek penilaian meliputi tingkat kepuasan Nasabah terhadap fasilitas sarana dan prasarana, ragam produk dan keuntungan naisbah bagi hasilnya serta kinerja karyawan dalam member pelayanan, rata-rata responden menjawab bahwa pola pelayanan terhadap ragam dan produk untuk menunjang pengembangan ekonomi umat kedepan. Dan kinerja yang di berikan telah memenuhi harapan para Nasabah sehingga Nasabah merasa puas.

\section{E. REFRENSI}

Antonio, Muhammad Syafi'i, (2000). Bank Islam Suatu pengenalan Umum, Cet I, Tazkia Institute,

Abdul Karim, Amrullah H. Abdul Malik, Prof. Dr. (1999). Tafsir Al-Azhar Jus 5, Jakarta: Pustaka Panjimas,

Departemen Agama RI (1989). Al-Qur'an dan Terjamahannya, Jakarta: Toha Putra,

Djalli, H. A, Jawariyadi, prof, Drs, M.Ag, Lembaga-lembaga Perekomian Umat ( Sebuah Pengenalan ), Ed.1, Cet.1,
Jakarta: PT RajaGrapindo Persada, 2002

Hadi, Surisno. (2004) Metodologi Research, Yogyakarta: Yayasan Penerbit Fakultas Psikologi UGM,

Mokodompit, Agussalim, MA. (2001). Metodologi Penelitian Sosial, Bandung: Usaha Pustaka,

Profil Pusat Inkubasi Bisnis Usaha Kecil, (Center For Micro Enterprize Incubation), Kantor BMT Ar-Rahmah Rappang, Kabupaten Sidrap

Rosyidi, Suherman. (2004). Pengantar Teori Ekonomi Pendekatan Kepada Ekonomi Mikro dan Makro, Ed.I, Cet.9, Jakarta: PT RajaGrapindo Persada,

Rahman, Afzalur. (2002). Doktrin Ekonomi Islam, Jilid 3, Cet.2, Yogyakarta: PT Dana Bhakti Prima Yasa,

Ridwan, Muhammad. (2004). Manajemen Baitul Maal wa Tamwil (BMT), Cet I; Yogyakarta: UII Press,

Sudarsono, Heri. (2003). Bank dan Lembaga Keuangan Syariah Deskripsi dan Ilustrasi, Ed.1, Yogyakarta: Ekonisia,

Taqiyuddin an Nabhani, (2001). Membangun Sistem Ekonomi Alternatif Prespektif Isam (terj.), Surabaya: Risalah Gusti. 